J. Perinat. Med. $16(1988) 99$

\section{The relationship of hypoxia to hypoxanthine concentration during pregnancy and delivery}

\author{
Ernst P. Issel ${ }^{1}$, Andreas Lun², Renate Pohle ${ }^{2}$, and Johann Gross ${ }^{2}$ \\ ${ }^{1}$ Department of Obstetrics and Gynecology, School of Medicine, Martin-Luther- \\ University, Halle-Wittenberg, and \\ ${ }^{2}$ Institute of Pathological and Clinical Biochemistry, School of Medicine (Charité \\ Hospital), Humboldt University, Berlin, German Democratic Republic
}

\section{Introduction}

Hypoxia results in an increase in hypoxanthine in tissues and blood [12]. Hypoxanthine, a metabolite of the purines, can permeate many cell membranes. Hypoxia causes disequilibrium in the synthesis and decomposition of ATP. Because ATP is needed for the resynthesis of adenylic nucleotides from hypoxanthine (Salvage pathway), resynthesis of adenylic nucleotides is limited. Finally, because of insufficient oxygen which acts as a substrate for the xanthine oxidase reaction, the synthesis of uric acid from hypoxanthine is also limited. Therefore hypoxanthine can be used as an indicator of the energy potential of the cells and as a parameter of the severity of hypoxia [12].

Studies of the usefulness of measurements of hypoxanthine concentration in plasma in order to evaluate the severity of hypoxia during the perinatal period in man, have produced varying results. Some authors have found a significant correlation between the concentration of hypoxanthine in blood from the scalp or the umbilical cord vessels of fetuses or neonates directly after delivery and biochemical parameters of hypoxia such as $\mathrm{pH}$, base deficit, lactate concentration, Apgar score, and clinical hypoxia scores $[8,16,17]$. Other authors have found no such relationship [7, 11].

Possible factors which complicate the relationship between the level of hypoxanthine and fetal hypoxia thus making use of measurements of hypoxanthine as an indicator difficult, include the following:
- possible placental transfer [5, 18, 19];

- increase in the concentration of hypoxanthine in plasma during physical exertion [10];

- increase in the hypoxanthine concentration in the amniotic fluid during labor with no accompanying manifestations of hypoxia in either mother or fetus [6];

- hypoxanthine concentration in the placental tissues [14];

- increased hypoxanthine concentration in women with complications of pregnancy [6].

Since the results found in the literature are contradictory, we attempted to find answers to the following questions:

1. Does the concentration of hypoxanthine in maternal plasma change during pregnancy?

2. Is there a correlation between maternal and fetal hypoxanthine concentrations?

3 . Is the hypoxanthine concentration in the umbilical cord blood an indication of hypoxia?

\section{Patients and methods}

\subsection{Blood sampling}

Blood was taken from the cubital vein of 15 to 16 patients in each of the following groups:

- healthy non-pregnant women;

- normal women in the 11 th to the 20 th week of pregnancy;

- normal women in the 22 nd to 41 th week of pregnancy; 
- women with a complicated pregnancy in the 25 th to 40 th week of pregnancy.

Maternal age and the number of previous pregnancies was equally distributed among the groups.

During delivery of the fetal head, blood was taken from the cubital vein of the mother in 42 cases (20 normal and 22 complicated deliveries). Additionally, after the umbilical cord was cut, blood was taken from both the umbilical artery and vein. Blood was taken from 7 women delivered by cesarean section before and during anesthesia. Blood was taken every 10 seconds $(10-20$ samples per case) from 5 normal women during labor. The exact sampling times were marked on the cardiotocogram (CTG) and assigned to the appropriate phase of uterine contractions according to the curve in table III. Blood was taken from the vein of the mother in 19 normal births at 5 and 60 minutes after delivery.

All births were monitored using internal CTG.

\subsection{Preparation of blood samples}

One $\mathrm{ml}$ of blood was drawn for each sample. This amount was immediately divided into two $0.5 \mathrm{ml}$ portions and the protein precipitated using $5 \mathrm{ml}$ of frozen uranyl acetate. Within the next $20 \mathrm{~min}$ utes the sample was contrifuged and the supernatant frozen at $-20^{\circ} \mathrm{C}$.

\subsection{Assay for hypoxanthine}

The hypoxanthine assay was done according to the methods described by GARDINER [3] and LUN et al. [10]. Samples could be identified by the laboratory only by their registration numbers. Even the 2 portions of the same sample could not be related to each other in the laboratory.

The double-assay precision control resulted in the following (arranged according to the hypoxanthine concentration and calculated as standard deviation (SD)):

$$
\begin{array}{rll}
0.0-3.0 \mu \mathrm{mol} & \mathrm{n}=138 & \mathrm{SD}= \pm 1.7 \mu \mathrm{mol} / 1 \\
3.1-10.0 \mu \mathrm{mol} & \mathrm{n}=140 & \mathrm{SD}= \pm 1.7 \mu \mathrm{mol} / 1 \\
>10.0 \mu \mathrm{mol} & \mathrm{n}=22 & \mathrm{SD}= \pm 1.5 \mu \mathrm{mol} / 1
\end{array}
$$

\subsection{Statistical evaluation}

Variance analysis ( $\mathrm{H}$ test) was used for the statistical analysis of variations in hypoxanthine concentrations in small numbers (cf. tables I, II, VI, VII) [2]. In order to check the changes in hypoxanthine concentrations in each woman during and after birth (table IV), the Wilcoxon test for differences in pairs was used [2]. Also, the $t$ test was used for comparison of average values of test data. The chi square test was used to calculate the significance of differences in factors (for example, the Apgar score) among groups [2]. Results with a probability of being due to chance of $<0.05$ were considered to be significant.

\subsection{Criteria used to define the subgroups}

Variable decelerations were considered to be severe when there was a decrease in frequency of more than $60 \mathrm{bpm}$ or when the frequency fell below $80 \mathrm{bpm}$.

An intranatal CTG was considered as indicating complications when severe variable deceleration appreared regularly for more than 20 minutes or late decelerations occurred, when a severe bradycardia (under $80 \mathrm{bpm}$ ) continued for longer than 10 minutes, or when mild bradycardia or tachycardia continued for more than 20 minutes and was accompanied by lowered oscillation amplitude or mild variable decelerations.

The neonate was considered to be severely depressed when a $\mathrm{pH}$ of below 7.10 was measured and the Apgar score remained $<8$ after 5 minutes. Neonates with a pH above 7.20 and an Apgar score above 8 within 1 minute were considered to be normal. Neonates with results between these two categories were classified as slightly depressed.

\section{Results}

During pregnancy there were no significant changes in the maternal serum hypoxanthine concentrations (table I). The small decrease in the concentration seen during the later stages of normal pregnancy could be the result of the increased perfusion of the kidneys occurring during pregnancy. Even in those pregnancies with complications, there was no increase in hypoxanthine concentration.

During the course of labor, there was an increase in the hypoxanthine concentration in maternal venous blood. The average values doubled: Range in normal pregnancy, 2.9 to $4.1 \mu \mathrm{mol} / 1$ and in spontaneous birth, 9.4 to $11.8 \mu \mathrm{mol} / 1$ (see tables I and II).

In vaginal instrumental delivery, hypoxanthine concentration was found to be only slightly higher than in a normal pregancy. There was no differ- 
Table I. Hypoxanthine concentrations in the venous blood of pregnant and non-pregnant women

\begin{tabular}{|c|c|c|c|c|}
\hline \multirow[t]{2}{*}{ Group } & \multirow[t]{2}{*}{$\mathbf{n}$} & \multicolumn{3}{|c|}{ Hypoxanthine in $\mu \mathrm{mol} / 1$} \\
\hline & & $\overline{\mathbf{x}}$ & SD & Range \\
\hline Healthy non pregnant & 15 & 5.0 & 2.6 & $0.6-9.4$ \\
\hline Normal pregnancy $(19-20$ gestational weeks) & 15 & 4.1 & 4.4 & $0.0-12.6$ \\
\hline Normal pregnancy $(22-41$ gestational weeks) & 16 & 2.9 & 2.0 & $0.9-9.1$ \\
\hline Complicated pregnancy ( $25-40$ gestational weeks) & 16 & 2.9 & 2.0 & $0.3-8.7$ \\
\hline Gestosis & 1 & $(2.0)$ & & \\
\hline Pyelonephritis & 3 & (1.8; & 5.0 & 8.7) \\
\hline Diabetes mellitus & 3 & $(1.2$ & 1.4; & 2.8) \\
\hline Threatened premature labor & 2 & $(2.2 ;$ & 4.1) & \\
\hline Heart abnormality & 3 & $(1.0$ & 3.2 & 3.8) \\
\hline $\mathrm{Rh}$ immunization (Liley II) & 2 & (2.5; & 3.4) & \\
\hline Hepatosis & 2 & $(0.3)$ & & \\
\hline Cholelithiasis & 1 & (2.4) & & \\
\hline
\end{tabular}

( ): individual values

No significant difference among groups

Table II. Influence of the type of birth on the hypoxanthine concentration in maternal plasma

\begin{tabular}{|c|c|c|c|c|c|}
\hline \multirow[t]{2}{*}{ Group } & \multirow[t]{2}{*}{$\mathrm{n}$} & \multicolumn{3}{|c|}{ Hypoxanthine in $\mu \mathrm{mol} / \mathrm{l}$} & \multirow[t]{2}{*}{$\mathbf{P}$} \\
\hline & & $\overline{\mathbf{x}}$ & SD & Range & \\
\hline Spontaneous birth ( $\leq 10$ hours) & 22 & 9.4 & 9.8 & $2.5-39.0^{*}$ & \\
\hline Spontaneous birth ( $>10$ hours) & 14 & 11.8 & 7.2 & $2.4-31.0^{*}$ & \\
\hline $\begin{array}{l}\text { Vaginal instrumental or complicated delivery } \\
\text { Forceps delivery } \\
\text { Vacuum extraction } \\
\text { Breech presentation }\end{array}$ & $\begin{array}{ll}6 & \\
2 \\
2 \\
2\end{array}$ & 6.9 & 1.8 & $4.5-9.1$ & \\
\hline $\begin{array}{l}\text { Cesarean section } \\
\text { before anesthesia } \\
\text { during anesthia in the course of delivery }\end{array}$ & 7 & $\begin{array}{l}4.6 \\
3.6\end{array}$ & $\begin{array}{l}2.0 \\
2.4\end{array}$ & $\begin{array}{l}2.5-7.4 \\
1.5-8.6\end{array}$ & n.s. \# \\
\hline
\end{tabular}

\# significant difference between the groups "Cesarean section" and "spontaneous birth" both under and over 10 hours of duration $\mathrm{p}<0.05$

* significant difference to normal pregnancy (table I) $p<0.05$

ence between the hypoxanthine concentrations during spontaneous birth on the one hand and after operative vaginal deliveries on the other. When the hypoxanthine concentration in normal pregnancy was compared to the concentration after cesarean section or anesthesia, no difference was detected (table III and figure 1). There were no changes in the concentration of hypoxanthine relating to uterine contraction. Within one hour after delivery, raised hypoxanthine levels had returned to normal (table IV).
On the basis of the 42 cases in which the hypoxanthine concentrations in the mother's blood, in that from the umbilical artery and vein were measured concurrently, we can see that the hypoxanthine concentration in the mother $(9.8 \pm 8.4 \mu \mathrm{mol} / \mathrm{l})$ was higher than that in the umbilical cord vessels (vein, $5.9 \pm 3.1 \mu \mathrm{mol} / \mathrm{l}$; artery, $6.4 \pm 3.2 \mu \mathrm{mol} / \mathrm{l}$ ).

There was no significant difference between the concentrations in the umbilical vein and the artery (paired analysis). As can be seen in table V, the 
Table III. The relationship of hypoxanthine concentration in maternal venous blood to the phase of the contraction cycle

\begin{tabular}{lrll} 
Phase of contraction & $\mathrm{n}$ & \multicolumn{2}{l}{ Hypoxanthine concentration $(\mu \mathrm{mol} / \mathrm{l})$} \\
\cline { 3 - 4 } & & $\overline{\mathrm{x}}$ & $\mathrm{SD}$ \\
\hline (1) Beginning of contraction & 7 & 4.4 & 1.1 \\
(2) Climax of contraction & 5 & 5.2 & 1.9 \\
(3) Fading contraction & 9 & 5.0 & 1.3 \\
(4) First half of the interval between contractions & 22 & 4.2 & 1.4 \\
(5) Second half of the interval between contractions & 22 & 5.0 & 1.7 \\
\hline
\end{tabular}

No difference between the phases of the contraction cycle

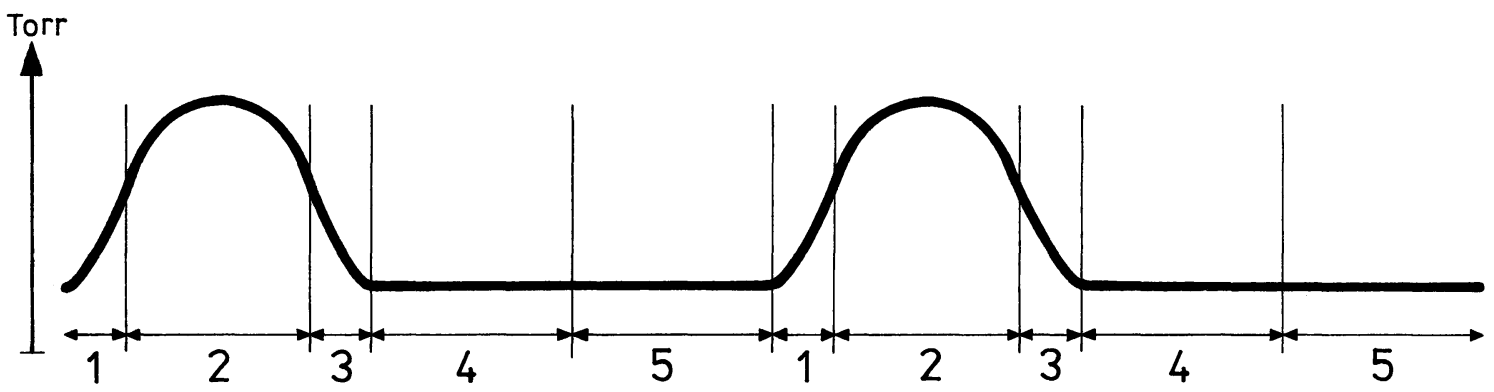

Figure 1. Phases of the contraction cycle investigated (cf. table III).

Table IV. Decrease of maternal venous hypoxanthine concentration after delivery $(\mathrm{n}=19)$

\begin{tabular}{lll}
\hline Time of sampling & \multicolumn{2}{l}{$\begin{array}{l}\text { Hypoxanthine concen- } \\
\text { tration }(\mu \mathrm{mol} / \mathrm{l})\end{array}$} \\
\cline { 2 - 3 } & $\overline{\mathrm{x}}$ & $\mathrm{SD}$ \\
\hline 5 min. before delivery & 4.0 & 2.0 \\
5 min. after delivery & 6.5 & $3.8 \mathrm{n} . \mathrm{s}$. \\
60 min. after delivery & 2.3 & $1.4 \mathrm{p}<0.01$ \\
\hline
\end{tabular}

mean hypoxanthine concentrations in both the umbilical artery and the umbilical vein are higher in damaged neonates (mild plus severly damaged) than in normal neonates.

Classifying the neonates according to the CTG during birth, we found that, when there were mild anomalies in the CTG, the average values of the hypoxanthine concentrations were a bit higher (umbilical vein $5.4 \mu \mathrm{mol} / 1$, artery $6.4 \mu \mathrm{mol} / \mathrm{l}$ ) than when the CTG was normal (umbilical vein 5.1

Table V. The relationship of hypoxanthine concentration in plasma from the umbilical artery and umbilical vein to the degree of neonatal depression

\begin{tabular}{|c|c|c|c|c|c|c|c|}
\hline \multirow[t]{3}{*}{ State of the neonate } & \multirow[b]{3}{*}{$\mathbf{n}$} & \multicolumn{6}{|c|}{ Hypoxanthine concentration $(\mu \mathrm{mol} / \mathrm{l})$} \\
\hline & & \multicolumn{3}{|c|}{ Umbilical vein } & \multicolumn{3}{|c|}{ Umbilical artery } \\
\hline & & $\overline{\mathrm{x}}$ & SD & Range & $\overline{\mathbf{x}}$ & SD & Range \\
\hline Normal & 28 & 4.7 & 2.0 & $2.5-11.4$ & 5.5 & 2.2 & $2.2-11.7$ \\
\hline Slightly depressed & 11 & 7.6 & 3.5 & $3.0-8.4$ & 8.0 & 3.4 & $1.0-14.9$ \\
\hline Severely depressed & 3 & 10.0 & & $10.0-12.0$ & 9.1 & & $2.0-13.2$ \\
\hline Total & 42 & 5.9 & 3.1 & $10.0-15.7$ & 6.4 & 3.2 & $2.0-14.9$ \\
\hline
\end{tabular}

Significant differences between normal and depressed neonates (slightly and severely), $\mathrm{p}<0.05$ 
$1 \mathrm{~mol} / 1$, artery $5.3 \mu \mathrm{mol} / 1$ ); this difference is not significant. When the CTG was abnormal, the values were higher (umbilical vein $10.0 \mu \mathrm{mol} / \mathrm{l}$, artery $9.6 \mu \mathrm{mol} / 1$, table VI).

A similar result was obtained when we compared the cases according to THIRINGER's asphyxia score ([16], table VII). Only when the score was clearly higher than normal (3-10 points) was the concentration of hypoxanthine in the umbilical cord vessels also above normal.

The correlation coefficients of the data from 42 births showed only a weak relationship between the hypoxanthine concentrations in the umbilical veins and the umbilical arteries on the one hand, and parameters which are considered to be related to intranatal hypoxia, on the other (table VIII). These parameters included the 1 and 5 minute Apgar scores, umbilical arterial $\mathrm{pH}$ and the duration of labor.

\section{Discussion}

On the basis of our results the questions posed at the beginning of this paper can be answered as follows:

1. The hypoxanthine concentration in the maternal cubital vein blood is not higher in the pregnant than in the non-pregnant woman. It is also no higher in complicated pregnancy. HAYASHI [5] and other authors did find higher hypoxanthine concentrations in the plasma of pregnant women with toxemia. It seems that the increase in concentration is thus dependent on the type and the severity of the complication.

2. During birth, there is a significant increase in the hypoxanthine concentration in the maternal venous blood. This can reach almost twice the level found before birth (see table I, table II, O'CoNNER et al. [11]). Sometimes extremely high

Table VI. Relationship between the hypoxanthine concentration in the umbilical vessels and intranatal CTG changes

\begin{tabular}{llcc}
\hline CTG & & \multicolumn{2}{l}{ Hypoxanthine concentration $(\mu \mathrm{mol} / \mathrm{l})$} \\
\cline { 3 - 4 } & & Umbilical vein & Umbilical artery \\
\hline Normal & $\mathrm{n}$ & 20 & 20 \\
& $\mathrm{x}$ & 5.1 & 5.3 \\
Slightly anomal & $\mathrm{SD}$ & 1.8 & 1.9 \\
& $\mathrm{n}$ & 14 & 14 \\
Severely anomal & $\mathrm{x}$ & 5.4 & 6.4 \\
& $\mathrm{SD}$ & 1.9 & 8 \\
& $\mathrm{n}$ & 1.5 & $9.6^{*}$ \\
& $\mathrm{x}$ & $3.0^{*}$ & 4.5 \\
\hline
\end{tabular}

* Difference from normal group, $\mathrm{p}<0.05$

Table VII. Relationship between the hypoxanthine concentration in umbilical vessels and THIRINGER's asphyxia score [16]

\begin{tabular}{llll}
\hline Asphyxia score & & \multicolumn{2}{l}{ Hypoxanthine concentration $(\mu \mathrm{mol} / \mathrm{l})$} \\
\cline { 3 - 4 } & & Umbilical vein & Umbilical artery \\
\hline $0-1$ & $\mathrm{n}$ & 25 & 25 \\
& $\overline{\mathrm{x}}$ & 4.9 & 5.5 \\
2 & $\mathrm{SD}$ & 2.1 & 2.6 \\
& $\mathrm{n}$ & 9 & 9 \\
& $\overline{\mathrm{x}}$ & 5.3 & 2.5 \\
$3-10$ & $\mathrm{SD}$ & 2.5 & 8 \\
& $\mathrm{n}$ & 8 & 8.2 \\
& $\overline{\mathrm{x}}$ & $9.8^{*}$ & 4.9 \\
\hline
\end{tabular}

* Difference from control group asphyxia score $0-1, \mathrm{p}<0.05$ 
Table VIII. Correlation coefficients of the data from 42 births

\begin{tabular}{|c|c|c|c|c|c|c|}
\hline \multirow[t]{3}{*}{ Parameter } & \multicolumn{2}{|c|}{ Hypoxanthine } & \multicolumn{2}{|c|}{ Apgar score } & \multirow{3}{*}{$\begin{array}{l}\mathrm{pH} \\
\text { umbilical a. }\end{array}$} & \multirow{3}{*}{$\begin{array}{l}\text { Duration } \\
\text { of labor }\end{array}$} \\
\hline & \multirow{2}{*}{$\begin{array}{l}\text { Maternal } \\
\text { cubital vein }\end{array}$} & Fetus & \multirow[t]{2}{*}{$1 \mathrm{~min}$} & \multirow[t]{2}{*}{$5 \mathrm{~min}$} & & \\
\hline & & umbilical v. umbilical a. & & & & \\
\hline
\end{tabular}

\begin{tabular}{|c|c|c|c|c|c|c|c|}
\hline HX umb. v. & 0.14 & & & & & & \\
\hline HX umb. a. & $0.36^{*}$ & $0.62 *$ & & & & & \\
\hline Apgar 1' & -0.04 & $-0.44^{*}$ & -0.19 & & & & \\
\hline Apgar $5^{\prime}$ & -0.09 & $-0.42 *$ & -0.21 & $0.65^{*}$ & & & \\
\hline $\mathrm{pH}$ & -0.16 & $-0.50^{*}$ & $-0.43^{*}$ & $0.46^{*}$ & 0.23 & & \\
\hline Duration of labor & 0.28 & -0.02 & $0.46^{*}$ & -0.18 & -0.24 & $-0.36^{*}$ & \\
\hline Maternal age & 0.01 & 0.23 & -0.02 & -0.02 & 0.09 & $0.33^{*}$ & $-0.45^{*}$ \\
\hline
\end{tabular}

* Explorative analysis of correlations, $\mathrm{p}<0.05$

$\mathrm{HX}=$ Hypoxanthine

levels (up to $39.0 \mu \mathrm{mol} / 1$ ), much higher than the highest found in hypoxic fetuses in this study (maximum $15.7 \mu \mathrm{mol} / \mathrm{l}$ ), are found without even the slightest symptoms of hypoxia. We suggest that this is caused by the work which the mother has to perform during the birth process (uterine contractions, the voluntary muscular effort involved in expulsion of the fetus etc.). The hypoxanthine concentration was not found to vary with the phases of contractions (table III). Probably the uterus secretes only small amounts of hypoxanthine during contractions. It is the total effort involving the entire body which leads to an increase in the hypoxanthine concentrations in the venous blood during the last phase of birth. The hypoxanthine concentration has been reported to exhibit similar behavior in association with the effort expended in sporting activity: it rose rapidly in subjects exercising on a bicycle ergometer, but remained constant in fencers whose sport requires quick, strong movements [10]. The raised levels of hypoxanthine we found in the mother returned to normal within one hour (table IV).

The hypoxanthine concentrations during cesarean sections are as low as those observed during pregnancy since the mother would experience only a short and weak labor (table II).

3. The hypoxanthine concentrations in cord blood of neonates after normal gestation and birth was similar to those found in neonates on the first day of life [7, 9].

There was a considerable difference in the concentration of hypoxanthine we found in plasma from umbilical blood and that reported by other au- thors. We attribute this to differences in assay methods. The values found by the WALLENBURG team $[18,19]$ using photometry were between 20 and $30 \mu \mathrm{mol} / \mathrm{l}$; those found by SAUGSTAD $[12,16]$ using oxygen electrodes were between 6 and 16 $\mu \mathrm{mol} / \mathrm{l}$; the average found by LIPP-ZWAHLEN [8], also with oxygen electrodes, lay between 11 and $20 \mu \mathrm{mol} / 1$; and the values obtained by O'CONNER et al. using HPLC [11] were between 4.2 and 8.8 $\mu \mathrm{mol} / \mathrm{l}$. These last values were in the range of the values we obtained with fluorometrical methods.

4. The hypoxanthine concentration in fetal blood during birth is not dependent on the average concentration in the maternal blood. The slight correlation between the concentrations in the venous blood of the mother and umbilical arterial blood ( $r=0.36$, table VIII) must be considered to be a random result, since there was a strong relationship between the concentrations in the umbilical artery and the vein on the one hand and no relationship between the concentrations in maternal blood and umbilical venous blood on the other.

5. When symptoms of hypoxia were observed in a neonate, then the hypoxanthine concentrations in the umbilical vessels were high. These symptoms include a depressed state of the neonate (table V), anomalies of the CTG during delivery (table VI), and a high Thiringer asphyxia score ([16], table VII). Correlations between the hypoxanthine concentrations in the umbilical vessels, on the one hand, and the $\mathrm{pH}$ of the neonate and the 1 and 5 minutes Apgar scores, on the other, and also between the umbilical arterial hypoxan- 


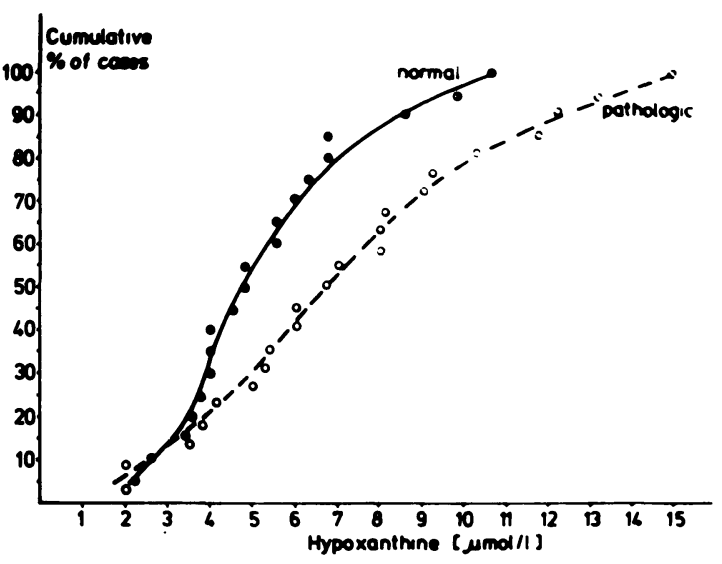

Figure 2. Cumulative distribution of the hypoxanthine concentration in umbilical artery blood for normal $(n=20)$ and abnormal $(n=22)$ births.

thine concentration and the duration of labor all demonstrate that high hypoxanthine concentrations are more frequent in the hypoxic than in the normal fetus.
When we plot the normal cases (i.e. normal pregnancy, normal birth without CTG abnormalities and undamaged neonates; $n=20$ ) and the pathological cases $(n=22)$ against the hypoxanthine concentration in the umbilical artery, we get the cumulative frequency curve shown in figure 2 . The 9 th centile of normal cases lies at $8.6 \mu \mathrm{mol} / 1$. From the curves it can be seen that no matter how high one sets the threshold value no clinically useful differentiation between normal and pathological cases can be achieved by using hypoxanthine concentration values.

Whether an extremely high hypoxanthine concentration can be considered to indicate a risk of hypoxic brain damage $[4,15]$ cannot be answered from the results of this study. Because the births were well-managed, the hypoxanthine concentrations in umbilical cord blood did not reach high levels. The five neonates with hypoxanthine concentrations above $12 \mu \mathrm{mol} / 1$ showed normal psychomotoric development at 1 to 2 years of age.

The literature suggests that the hypoxanthine concentration relates more to postnatal than intranatal hypoxia $[1,13,15]$.

\begin{abstract}
The concentration of hypoxanthine in plasma was suggested as an indicator of hypoxic conditions in newborns. We examined the concentration of hypoxanthine in maternal venous as well as in umbilical cord blood during pregnancy and during and after labor. The concentration of hypoxanthine in the cubital venous blood of nonpregnant healthy women and in healthy pregnant women and in women with complicated pregnancies was the similar.

During birth there is an increase of the hypoxanthine concentration in maternal blood. This could be caused by the muscular work involved in giving birth (contraction, pushing, breathing). The values increased from
\end{abstract}

2.0 - 4.1 $\mu \mathrm{mol} / 1$ in normal and abnormal pregnancy up to values of $9.4-11.8 \mu \mathrm{mol} / 1$ immediately after delivery. At the end of delivery the level of hypoxanthine is higher in the venous blood of the mother than in the umbilical blood. The concentration of hypoxanthine in umbilical venous blood and umbilical arterial blood did not show any significant differences.

When clinical symptoms of hypoxia (depressed state of the neonate, high Thiringer asphyxia score, low Apgar score) were observed in the neonate, the hypoxanthine concentration in the umbilical vessels was increased (normal $4.7 \mu \mathrm{mol}(\mathrm{l}$; slightly depressed $7.6 \mu \mathrm{mol} / \mathrm{l}$, severely depressed $10 \mu \mathrm{mol} / \mathrm{l})$.

Keywords: Apgar score, cord blood, hypoxanthine, hypoxia, pregnancy.

\section{Zusammenfassung}

Die Hypoxanthinkonzentration in der Schwangerschaft und unter der Geburt in Beziehung zu Hypoxiezuständen Sowohl unter Hypoxie als auch bei schwerer körperlicher Arbeit kommt es zu einem Ansteigen der Hypoxanthinkonzentration im Plasma. Wegen unterschiedlicher Auffassungen in der Literatur wollten wir folgende Fragestellungen bearbeiten:
1. Ändert sich der Hypoxanthinspiegel im mütterlichen Plasma während der Schwangerschaft?

2. Bestehen zwischen mütterlicher und fetaler Hypoxanthinkonzentration Korrelationen?

3. Charakterisiert die Hypoxanthinkonzentration im Nabelschnurblut fetale Hypoxiezustände? 
Dazu wurden von folgenden Patientengruppen Blutproben entnommen:

- von gesunden Nichtschwangeren, Frauen mit normaler Früh- und Spätschwangerschaft sowie bei pathologischem Schwangerschaftsverlauf $(n=15-16)$,

- von 42 Kreißenden und ihren Neugeborenen (A. et V. umbilicalis) unter der Geburt.

- von 7 Kaiserschnittentbindungen,

- von 5 Kreißenden in Abhängigkeit von der Wehenphase,

- von 19 Fällen unter der Geburt und 1 Stunde danach.

Die Doppelbestimmungen der Hypoxanthinkonzentration erfolgten nach GARDINER [3] und LuN et al. [10] fluorometrisch.

Die Schwangerschaft führt weder bei normalem noch bei pathologischem Verlauf zu einem Anstieg der Hypoxanthinkonzentration (Tab. I). Am Ende der Geburt kommt es zu einem signifikanten Anstieg der Hypoxanthinkonzentration im mütterlichen Venenblut (Schwangerschaft: Mittelwerte 2,9 bis $4,1 \mu \mathrm{mol} / 1$, vaginale $\mathrm{Ge}-$ burt: Mittelwerte 9,4 bis 11,8 $\mu \mathrm{mol} / \mathrm{l})$. Durch die Intubationsnarkose zum Kaiserschnitt wird die mütterliche Hypoxanthinkonzentration nicht beeinflußt. Die zum Ende der Geburt hin angestiegenen Hypoxanthinkonzentrationen fallen innerhalb einer Stunde postnatal wieder auf die Normalwerte ab (Tab. IV).

Am Ende der Geburt liegen die mütterlichen Hypoxanthinkonzentrationen $(\mathrm{x}=9,4 \mathrm{bzw} .11,8 \mu \mathrm{mol} / \mathrm{l})$ signifi- kant höher als die Werte in den Nabelschnurgefäßen (Nabelarterie 6,4 $\pm 3,2 \mu \mathrm{mol} / 1$, Nabelvene 5,9 $\pm 3,1$ $\mu \mathrm{mol} / \mathrm{l})$. Die Hypoxanthinkonzentrationen zwischen Nabelvene und Nabelarterie zeigen keine signifikanten Unterschiede. In beiden Nabelschnurgefäßen liegt die mittlere Hypoxanthinkonzentration bei deprimierten Neugeborenen etwa doppelt so hoch wie bei nicht deprimierten Kindern (Tab. V).

Bei pathologischem CTG unter der Geburt sind die Hypoxanthinkonzentrationen in Nabelarterie und $\mathrm{Na}-$ belvene doppelt so hoch wie bei normalem CTG (Tab. V).

Die statistischen Zusammenhänge zwischen Hypoxanthinkonzentration in den Nabelschnurgefäßen und den Parametern der Hypoxie (Apgar-Score nach 1 und 5 Minuten, Nabelarterien-pH, Geburtsdauer) sind jedoch nur lockerer Natur. Die Absolutwerte der Korrelationskoeffizienten liegen nur zwischen $\mathrm{r}=0,34$ und 0,50 (Tab. VIII). Die kumulativen Häufigkeitsverteilungen der Hypoxanthinkonzentrationen von normalen und pathologischen Geburten (Abb. 2) differieren nicht ausreichend, um die Hypoxanthinkonzentration im Nabelschnurblut als Parameter für die Unterscheidung hypoxischer und normoxischer Neugeborener zu verwenden.

Beim Vergleich mit der Literatur scheint die Hypoxanthinkonzentration hinsichtlich postnataler Hypoxiezustände aussagekräftiger zu sein als hinsichtlich hypoxischer Zustände unter der Geburt [1, 13, 15].

Schlüsselwörter: Apgar Score, Hypoxanthin, Hypoxie, Nabelschnurblut, Schwangerschaft.

\section{Résumé}

\section{Relations entre l'hypoxie et les concentrations d'hypoxan-} thine pendant la grossesse et la naissance

L'hypoxie et les efforts physiques s'accompagnent d'une augmentation des concentrations d'hypoxanthine plasmatiques. En raison du fait que les rapports sur ce phénomène donnent des résultats variables, nous avons étudié les questions suivantes:

1. Les concentrations d'hypoxanthine dans le plasma maternel, se modifient-elles pendant la grossesse?

2. Existe t-il une corrélation entre les concentrations maternelles et fotales d'hypoxanthine?

3. La concentration d'hypoxanthine au sang du cordon ombilical est-elle un indicateur d'hypoxie?

Afin de répondre à ces questions, on a prélevé des échantillons sanguins parmi les groupes de patientes suivant:

- des femmes en bonne santé non enceintes, des femmes enceintes avec une grossesse normale, en début et en fin de grossesse, et des femmes enceintes avec une grossesse pathologique $(n=15,16)$,

- des femmes en travail et leurs nouveaux-nés (sang ombilical artériel et veineux $(n=42)$,

- des femmes césarisées $(n=7)$,

- des femmes en cours de travail, à différents stades du travail
- des nouveaux-nés pendant la naissance et une heure après $(n=19)$.

Les déterminations des concentrations d'hypoxanthine ont été réalisées par méthode flurométrique de GARDINER [3] et LUN et collaborateurs [10].

Pas une grossesse normale, ni une grossesse compliquée, n'a conduit à une augmentation des concentrations dans le sang veineux maternel (tab. I). A la fin du processus de la naissance, il y a une augmentation significative des concentrations d'hypoxanthine dans le sang veineux maternel (moyenne pendant la grossesse $=2,9$ à 4,1 micro mol/l, moyenne, naissance par voie basse 9,4 à $11,8 \mathrm{micro} \mathrm{mol} / \mathrm{l})$. La perfusion d'anesthésique pour une césarienne, n'influence pas la concentration d'hypoxanthine.

Les concentrations les plus élevées qui apparaissent à proximité de la fin du processus de la naissance, retournent à la normale en une heure après la naissance (tab. IV).

A la fin du processus de la naissance, les concentrations maternelles d'hypoxanthine ( $\mathrm{x}=9,4$ ou $11,8 \mathrm{micro} \mathrm{mol} /$ 1) sont significativement plus élevées que les concentrations dans les vaisseaux ombilicaux (artère ombilicale $=6,4 \pm 3,2 \mathrm{micro} \mathrm{mol} / \mathrm{l} ;$ veine ombilicale $=5,9 \pm 3,1$ micro mol/1). Il n'y a pas de différence significative 
entre les concentrations d'hypoxanthine dans la veine ombilicale et dans l'artère ombilicale. Chez les nouveaux-nés traumatisés, les concentrations d'hypoxanthine dans les vaisseaux ombilicaux artériels ou veineux sont environ le double de ceux des vaisseaux des nouveaux-nés bien portants. (tab. V).

Lorsqu'il y a des anomalies sur le CTG en cours de naissance, les concentrations d'hypoxanthine dans l'artère et dans la veine ombilicale sont deux fois plus élevées que lorsque le CTG est normal (tab. VI).

La relation statistique entre les concentrations d'hypoxanthine dans les vaisseaux ombilicaux et les paramètres d'hypoxie (score d'Apgar à 1 et 5 minutes, $\mathrm{pH}$ de l'artère ombilicale, durée du processus de la naissance) est cependant faible. Les valeurs absolues de coefficients de corrélation sont seulement entre $r=0,34$ et 0,50 (tab. VIII). Les distributions de fréquence cumulative des naissances normales et compliquées (figure 2) ne varient pas assez pour garantir l'utilisation des concentrations d'hypoxanthine dans les vaisseaux ombilicaux comme paramètre de distinction entre les nouveaux-nés hypoxiques et non hypoxiques.

La littérature suggère que les concentrations d'hypoxanthine dépistent plus les hypoxies post-natales qu'intranatales $[1,13,15]$.

Mots-clés: Grossesse, hypoxanthine, hypoxie, sang artériel ombilical, sang veineux ombilical, score d'Apgar.

\section{References}

[1] Bratteby E, S Swanström: Hypoxanthine concentration in plasma during the first two hours after birth in normal and asphyxiated infants. Pediatr Res 16 (1982) 152

[2] Clauss G, H EbNer: Grundlagen der Statistik für Psychologen, Pädagogen und Soziologen, 7. Auflage, Volk und Wissen, Berlin 1983

[3] GARDINER DG: A rapid and sensitive fluorimetric assay for adenosine, inosine and hypoxanthine. Analyt Biochem 95 (1979) 377

[4] HaRkness RA, AGL Whitelaw, RJ Simmonds: Intrapartum hypoxia: the association between neurological assessment of damage and abnormal excretion of ATP metabolites. J Clin Pathol 35 (1982) 999

[5] Hayashi TT, D Gillo, H Robbins, RE Sabbagha: Simultaneous measurement of plasma and erythrocyte oxypurines. I. Normal and toxemic pregnancy. Gynecol Invest 3 (1972) 221

[6] Issel EP, A Lun, R PoHle, J Gross: Hypoxanthine levels in amniotic fluid: An indicator of fetal hypoxia? J Perinat Med 10 (1982) 221

[7] Jung D, A Lun, J ZinsmeYer, EL Grauel, J Gross: The concentration of hypoxanthine and lactate in the blood of healthy and hypoxic newborns. J Perinat Med 13 (1985) 43

[8] Lipp-Zwahlen AE, $P$ Tuchschmid, $M$ SilBERSCHMIDT, G DUC: Arterial cord blood hypoxanthine: A measure of intrauterine hypoxia. Biol Neonate 44 (1983) 195

[9] Lun A, D Jung, R Pohle, M BötTcher, EL GrauEl, J Gross: Hypoxanthinkonzentration im Blut von Neugeborenen. Z Med Lab Diagn 24 (1983) 47

[10] Mallmann B, A Lun, R Pohle: Biochemische Parameter-im Serum vor und nach körperlicher Belastung. Mitteil. Hypoxanthinkonzentration im Blut. Med Sport 25 (1985) 27

[11] O'Connor MC, RA HARKNess, RJ Simmonds, FE HYTTEN: The measurement of hypoxanthine, xanthine, inosine and uridine in umbilical cord blood and fetal scalp blood sample as a measure of fetal hypoxia. Br J Obstet Gynaecol 88 (1981) 381

[12] Saugstad, OD: Hypoxanthine as a measurement of hypoxia. Pediatr Res 9 (1975) 158

[13] Saugstad OD, L Gluck: Plasma hypoxanthine levels in newborn infants: A specific indicator of hypoxia. J Perinat Med 10 (1982) 266

[14] Simmonds RJ, SB COADo, RA HARKNESS, L DRURY, FE HYTTEN: Nucleotide, nucleoside and purine base concentrations in human placentae. Placenta 3 (1982) 29

[15] Swanström S, L-E Bratteby: Hypoxanthine as a test of perinatal hypoxia as compared to lactate, base deficit, and pH. Pediatr Res 15 (1982) 156

[16] THIRINGER K: Cord plasma hypoxanthine as a measure of fetal asphyxia. Acta Paediatr Scand 72 (1983) 231

[17] Thiringer K, OD SAugstad, I KJellmer: Plasma hypoxanthine in esteriorized, acutely asphyxiated fetal lambs. Pediatr Res 14 (1980) 905

[18] WALlenbURG HCS, BK VAN KREEL: Uric acid and oxypurines in pregnancy. 1. The human model: Fetal and maternal concentrations during labor. In: MAHRON M, ET RIPPMANN: Recent advances in EPH-gestosis. 10 International Meeting of Organisation Gestosis Cairo 2-4 Dec. 1978. Shorouk Press Cairo 1980

[19] Wallenburg HCS, BK VAN KReEL: Maternal and umbilical plasma concentrations of uric acid and oxypurines at delivery in normal and hypertensive pregnancy. Arch Gynecol 229 (1980) 7

Received August 5, 1985. Revised January 29, 1987. Accepted March 13, 1987.

Prof. Dr. sc. med. Johann Gross

Institute of Pathological and Clinical Biochemistry Charité, Humboldt University of Berlin

Schumannstraße 20/21

DDR-1040 Berlin

German Democratic Republic 